\title{
Effectiveness of Video Assisted Teaching Programme on Cannabis Abuse on Level of Knowledge among Undergraduate Students
}

\author{
Manisha $^{1}$, Joseph Jeganathan ${ }^{2}$ \\ ${ }^{1}$ Nursing Tutor, Akal College of Nursing, Eternal University, Baru Sahib, Distt Sirmore, \\ Himachal Pradesh, (INDIA) PIN -173101 \\ ${ }^{2}$ Head, Dept. of Nursing, IES University, Bhopal, Madhya Pradesh
}

Corresponding Author: Manisha

\begin{abstract}
Introduction: Cannabis is a one of the illegal substance used worldwide. Its abuse can affect us psychologically, socially, physiologically and the strategies used to overcome addiction is psycho-education, cognitive behavioral therapy, motivational enhancement therapy, contingency management, family based therapy and pharmacotherapy.

Aim: To evaluate effectiveness of video assisted teaching programme on cannabis abuse on level of knowledge among undergraduate students.

Method: A Quantitative pre experimental one group pre test and post test design. Research approach was adopted in which was conducted on 80 Undergraduate students by Non probability, Multi stage cluster sampling technique. The data collection tool consists of two parts socio demographic variables and structured knowledge questionnaire regarding cannabis abuse which consists of 40 items. The data was self administered and analysed using SPSS 23 done (descriptive and inferential statistics).
\end{abstract}

Findings: According to 1 st objective in pre test there were 54(67.5\%) undergraduate students' with poor knowledge , 26(32.5\%) undergraduate students' with average knowledge, 44(55\%) had average knowledge, 36(45\%) had good knowledge and in post test $248(60 \%)$ had average knowledge, 32(40\%) had good knowledge. Mean \& SD of Pre and Post test $1 \&$ Post test 2 score on level of knowledge of undergraduate students in which Mean \& SD of Pre Test is $12.56 \pm 3.607$, Post test 1 is
$25.21 \pm 6.915$ and post test 2 is $26.49 \pm 4.707$. $(\mathrm{f}=162.38 ; \mathrm{p}<0.001 * *)$.

Conclusion: The study reveals the fact that video assisted teaching significantly increases knowledge among undergraduate Students regarding cannabis abuse

Key words: Cannabis abuse, effectiveness, knowledge.

\section{INTRODUCTION}

Cannabis is a one of the illegal substance that is obtained from the cannabis sativa plant which is prepared in different form. There are various pharmacological active compounds in cannabis, 9-d-THC (Tetrahydrocannabinol) is responsible for addiction. ${ }^{1} \quad$ There are 340 chemical compounds other than cannabinoids and in cannabinoid cigarette there is more amount of carbon monoxide, tar and carcinogens ${ }^{2}$. It is usually smoked by cigarettes (joints), pipes, water pipes (bongs or hookahs), and cigars that are usually called blunts. ${ }^{3}$

Cannabis use disorder (CUD), is defined as the continued use of cannabis despite clinically significant impairment, ranging from mild to severe (ICD 10) ${ }^{2}$. Prevalence rates indicate that 13 million individuals worldwide have cannabis use disorder. Severe lifetime CUD rates are around $2 \%$, which are usually seen at 21 years of age. ${ }^{5}$ Experimenting during adolescence also produce vulnerability to chronic use.10There are various symptoms that are seen in CUD such as in 
psychological symptom are euphoria, relaxation, perceptual alterations, time distortion, infectious laughter, talkativeness, anxiety and panic reactions, short-term memory, attention, motor skills, reaction time, and skilled activities were impaired when a person is intoxicated. ${ }^{6}$ Physiological symptoms include chronic bronchitis, in reproductive system it lowers testosterone secretion, impairs sperm production, motility, and disrupts the ovulatory cycle in women. ${ }^{6}$ Effects on the cardiovascular system, includes the occurrence of tachycardia, arrhythmias, myocardial infarction and it also affects the peripheral vasculature and the cerebrovascular system 7 Cannabis also affects socially which includes accidents, family separation, loss of employment, failure in school, school dropout, increasing domestic violence, child abuse, and other crimes. ${ }^{9}$ In both adults and adolescent, success rates have been seen with cognitive behavioural therapy, psychoeducation, motivational enhancement therapy, contingency management, family based therapy and pharmacotherapy variety of medications have been investigated to check potential for effective treatment. Medications include bupropion, naloxone, dronabinol, nabilone, non cannabinoid agents. ${ }^{9,10,11}$ According to legislation (The NDPS Act, 1985) the government of INDIA One who cultivates, produces, manufactures, possesses, sells, purchases, transports, imports inter-State, exports interState or uses cannabis, shall be punishable. ${ }^{8}$

\section{Need for the study}

According to a survey report (2010) it was estimated that 13.1 million cannabis dependent people globally, prevalence peaked between 20-24 yrs. ${ }^{12}$ A global estimate by UNODC(2016), reported that 13.8 million young people are cannabis users. ${ }^{13}$ About $2.8 \%$ of Indians aged 10-75 years (3.1 crore individuals) are current users of any cannabis product. ${ }^{14,15}$ A quasiexperimental study showed that knowledge about drugs improved significantly $(p<0.005)$ between the pre-post-test. Pro- attitude towards smoking, alcohol drinking and hard drugs decreased significantly in the post-test $(p<0.004)$. Similarly, the drug refusal skills improved significantly $(p<0.028) .{ }^{10}$ After extensive review of the literature, researcher felt need for developing video assisted teaching programme on prevention off cannabis abuse and empower the undergraduate students with knowledge about cannabis abuse.

\section{Statement of the problem}

A Pre experimental study to evaluate the effectiveness of video assisted teaching programme on cannabis abuse on level of knowledge among undergraduate students of Sirmour (H.P)

\section{Objectives of the study}

1. To assess the pre-interventional level of knowledge on cannabis abuse among undergraduate students.

2. To develop and administer the video assisted teaching programme on cannabis abuse.

3. To evaluate the effectiveness of video assisted teaching programme on level of knowledge on cannabis abuse among undergraduates

4. To find out the association between pretest level of knowledge score on cannabis abuse and with the selected demographic variables of the undergraduate students.

\section{Operational Definitions}

Video assisted teaching programme on cannabis abuse: refers to the teaching programme that includes the concepts of cannabis abuse, which will be given by displaying video film for 30 minutes

\section{Hypotheses}

H1: There will be significant difference in pre test and post test mean score on level of knowledge regarding cannabis abuse at $\mathrm{p}<0.05$ level of significance

$\mathrm{H} 2$ : There will be significant association between pre-test scores on level of 
knowledge with the selected demographic variables of undergraduate students.

\section{METHODOLOGY}

Research Approach: Quantitative research approach was taken for the study.

Research Design: A Pre experimental one group pre test and post test design was used in this study.

Research setting: The Study was conducted at Govind Sagar Government Degree Colleges of Poanta, and Government P.G Degree Colleges Nahan, district Sirmour H.P.

\section{Population: TARGET POPULATION:}

Undergraduate students of Arts government colleges

\section{ACCESSIBLE POPULATION:}

Undergraduate students of Arts government colleges in dist. Sirmour H.P

Sampling: Sample: The Sample of this study includes undergraduate students of arts of government degree colleges of Poanta and Government P.G degree colleges Nahan.

Sampling technique: Non probability, Multi cluster sampling technique was used for this study

Sample size: The estimated sample size for the study was 80 undergraduate Students.

\section{Inclusion Criteria:}

1. Both girls and boys who were studying in selected government degree colleges of Dist Sirmour H.P

2. Undergraduate students who were studying in first year, arts

3. Undergraduate students who were in age group 17-24 years

4. Undergraduate Students who were present at the time of data collection

\section{Exclusion criteria:}

1. Undergraduate Students who were not willing to participate in this study.

2. Undergraduate Students who have attended any sessions on cannabis abuse

\section{Data collection instrument}

The data collection tool consists of two parts.

Part - I: Socio demographic sheet of undergraduate students: It includes variables such as Age, gender, residential area father's education, mother's education, father's occupation, mother's occupation, family monthly income and family history of cannabis use.

Part - II: Structured knowledge questionnaire on cannabis abuse which consists of 40 items.

Intervention Video assisted teaching programme which is developed by the researcher, teaching programmer involves video assisted teaching on cannabis abuse for half hour.

Plan for data analysis:

Descriptive statistics: Frequency, Percentage were used for socio demographic variables Mean \& SD for pre test, post test $1 \&$ post test 2 score on level of knowledge on cannabis abuse

Inferential statistics: paired t- test were used to compare the mean of pre and post test $1 \& 2$, chi-square to find out the association between pre test score of level of knowledge with socio demographic variables, ANOVA for comparing the mean of pre test, post test $1 \&$ post test 2

\section{RESULTS}

The data analysis is presented in the following section:

\section{SECTION-A}

Table-4.1:Frequency and percentage distribution of socio demographic variables of undergraduate students $(\mathrm{N}=80)$

\begin{tabular}{|c|c|c|c|c|}
\hline S.No. & Variables & Sub categories & Frequency(f) & Percentage $(\%)$ \\
\hline \multirow[t]{3}{*}{1.} & \multirow[t]{3}{*}{ Age(years) } & $17-18$ & 57 & 71.3 \\
\hline & & $19-20$ & 21 & 26.3 \\
\hline & & $21-22$ & 2 & 2.5 \\
\hline \multirow[t]{2}{*}{2.} & \multirow[t]{2}{*}{ Gender } & Male & 32 & 40.0 \\
\hline & & Female & 48 & 60.0 \\
\hline \multirow[t]{3}{*}{3.} & \multirow[t]{3}{*}{ Residential Status } & Rural & 67 & 83.8 \\
\hline & & Urban & 12 & 15.0 \\
\hline & & Semi Rural & 1 & 1.3 \\
\hline
\end{tabular}


Manisha et.al. Effectiveness of video assisted teaching programme on cannabis abuse on level of knowledge among undergraduate students.

\begin{tabular}{|c|c|c|c|c|}
\hline \multicolumn{5}{|c|}{ Table 4.1 Continued... } \\
\hline \multirow[t]{5}{*}{4.} & \multirow[t]{5}{*}{ Father's Education } & No formal education & 20 & 25.0 \\
\hline & & Primary & 13 & 16.2 \\
\hline & & Secondary & 24 & 30.0 \\
\hline & & Senior Secondary & 15 & 18.8 \\
\hline & & Graduation & 8 & 10.0 \\
\hline \multirow[t]{5}{*}{5.} & \multirow[t]{5}{*}{ Mother's Education } & No formal education & 19 & 23.8 \\
\hline & & Primary & 16 & 19.9 \\
\hline & & Secondary & 34 & 42.5 \\
\hline & & Senior Secondary & 7 & 8.8 \\
\hline & & Graduation & 4 & 5.0 \\
\hline \multirow[t]{6}{*}{6} & \multirow[t]{6}{*}{ Father's Occupation } & Unemployment & 15 & 18.8 \\
\hline & & Private Employee & 34 & 42.5 \\
\hline & & Self Employed & 16 & 20.0 \\
\hline & & Government Employee & 6 & 7.5 \\
\hline & & Retired & 1 & 1.3 \\
\hline & & Farmer & 8 & 10.0 \\
\hline \multirow[t]{4}{*}{7.} & \multirow[t]{4}{*}{ Mother's Occupation } & Private Employment & 6 & 7.5 \\
\hline & & Government Employee & 5 & 6.3 \\
\hline & & Self Employed & 2 & 2.5 \\
\hline & & Home Maker & 67 & 83.8 \\
\hline \multirow[t]{4}{*}{8.} & \multirow{4}{*}{ Family Monthly Income (Rs) } & Below 5000 & 30 & 37.5 \\
\hline & & $5001-10000$ & 36 & 45.0 \\
\hline & & $10001-20000$ & 9 & 11.3 \\
\hline & & Above 20000 & 5 & 6.3 \\
\hline 9. & Family History of cannabis abuse & Yes & 11 & 13.8 \\
\hline
\end{tabular}

\section{Section-B:}

Table 4.2 Frequency \& percentage distribution of pre test, post test1 and post test 2 scores on level of knowledge on cannabis abuse of undergraduate students, $(\mathrm{N}=\mathbf{8 0})$

\begin{tabular}{|l|l|l|l|l|l|l|}
\hline \multirow{2}{*}{ level of knowledge } & \multicolumn{2}{|l|}{ Pre test } & \multicolumn{2}{l|}{ Post test-1 } & \multicolumn{2}{l|}{ Post test-2 } \\
\cline { 2 - 7 } & f & \% & f & \% & f & \% \\
\hline Poor & 54 & 67.5 & 0 & 0 & 0 & 0 \\
\hline Average & 26 & 32.5 & 44 & 55 & 48 & 60 \\
\hline Good & 0 & 0 & 36 & 45 & 32 & 40 \\
\hline
\end{tabular}

Table 4.3: Mean \& SD of Pre test and Post test 1 score on level of knowledge on cannabis abuse among undergraduate students (N=80)

\begin{tabular}{|l|l|l|l|l|l|l|}
\hline & Mean \pm S.D. & Mean\% & Range & Mean Difference & t- value & p value \\
\hline Pre test & $12.56 \pm 3.607$ & 31.40 & $5-25$ & \multirow{2}{*}{12.650} & 15.29 & \multirow{2}{*}{ < $0.001 * *$} \\
\hline Post test 1 & $25.21 \pm 6.915$ & 63.00 & $14-39$ & & & \\
\hline \multicolumn{7}{|c|}{$*$ Highly Significant }
\end{tabular}

Table 4.4: Mean \& SD of Pre test and Post test-2 scores on level of knowledge on regarding cannabis abuse among undergraduate students $(\mathbf{N}=\mathbf{8 0})$

\begin{tabular}{|l|l|l|l|l|}
\hline & Mean \pm S.D. & Mean Difference & t- value & p value \\
\cline { 1 - 2 } Pre test & $12.56 \pm 3.607$ & \multirow{2}{|c|}{13.93} & 21.68 & $<0.001 * *$ \\
\hline Post test 2 & $26.49 \pm 4.707$ & & & \\
\hline \multicolumn{4}{|c|}{$*$ Highly Significant } \\
\end{tabular}

Table 4.5: Mean \& SD of Pre test and Post test 1 \&Post test 2 scores on level of knowledge on cannabis abuse among undergraduate students $(\mathbf{N}=\mathbf{8 0})$

\begin{tabular}{|c|c|c|c|}
\hline & Mean \pm S.D. & F value & p value \\
\hline Pre test & $12.56 \pm 3.607$ & \multirow{3}{*}{162.38} & \multirow{3}{*}{$<0.001 * *$} \\
\hline Post test -1 & $25.21 \pm 6.915$ & & \\
\hline Post test -2 & $26.49 \pm 4.707$ & & \\
\hline
\end{tabular}

Table 4.6 Domain wise Mean \& SD of Pre test and Post test 1\&Post test 2 scores on level of knowledge on cannabis abuse among undergraduate students $(\mathrm{N}=\mathbf{8 0})$

\begin{tabular}{|c|c|c|c|c|c|}
\hline S. No. & Domains & Test & Mean \pm SD & F value & p value \\
\hline \multirow[t]{3}{*}{1.} & \multirow[t]{3}{*}{ Concept of cannabis abuse } & Pre test & $3.14 \pm 2.02$ & \multirow[t]{3}{*}{102.99} & \multirow[t]{3}{*}{$0.001 * *$} \\
\hline & & Post test1 & $7.05 \pm 2.5$ & & \\
\hline & & Posttest2 & $8.23 \pm 2.35$ & & \\
\hline \multirow[t]{3}{*}{2.} & \multirow[t]{3}{*}{ Physiological effect on health } & Pre test & $2.73 \pm 1.25$ & \multirow[t]{3}{*}{69.88} & \multirow[t]{3}{*}{$0.001 * *$} \\
\hline & & Post test1 & $5.31 \pm 2.0$ & & \\
\hline & & Posttest2 & $5.73 \pm 1.65$ & & \\
\hline \multirow[t]{3}{*}{3.} & \multirow[t]{3}{*}{ Psychological effect on health } & Pre test & $2.29 \pm 1.09$ & \multirow[t]{3}{*}{28.4} & \multirow[t]{3}{*}{$0.001 * *$} \\
\hline & & Post test1 & $3.34 \pm 1.44$ & & \\
\hline & & Post test2 & $3.58 \pm 0.82$ & & \\
\hline
\end{tabular}


Manisha et.al. Effectiveness of video assisted teaching programme on cannabis abuse on level of knowledge among undergraduate students.

\begin{tabular}{|c|c|c|c|c|c|}
\hline \multicolumn{6}{|c|}{ Table 4.6 Continued... } \\
\hline \multirow[t]{3}{*}{4.} & \multirow{3}{*}{ Socio- cultural effect on health } & Pre test & $1.51 \pm 0.811$ & \multirow[t]{3}{*}{64.48} & \multirow[t]{3}{*}{$0.001 * *$} \\
\hline & & Post test1 & $2.83 \pm 1.13$ & & \\
\hline & & Posttest2 & $3.00 \pm 0.74$ & & \\
\hline \multirow[t]{3}{*}{5.} & \multirow[t]{3}{*}{ Legislation on cannabis use } & Pre test & $1.35 \pm 0.95$ & \multirow[t]{3}{*}{30.96} & \multirow[t]{3}{*}{$0.001 * *$} \\
\hline & & Posttest1 & $2.56 \pm 1.15$ & & \\
\hline & & Posttest2 & $2.65 \pm 1.24$ & & \\
\hline \multirow[t]{3}{*}{6.} & \multirow[t]{3}{*}{ Management of cannabis abuse } & Pre test & $1.55 \pm 1.13$ & \multirow[t]{3}{*}{47.27} & \multirow[t]{3}{*}{$0.001 * *$} \\
\hline & & Posttest1 & $4.13 \pm 1.87$ & & \\
\hline & & Posttest2 & $3.31 \pm 1.82$ & & \\
\hline
\end{tabular}

The result of the study revealed that there was significant gain and retention in level of knowledge on cannabis abuse. Therefore the hypothesis was accepted.

\section{SECTION-C:}

Table 4.7 Association between pre test scores of level of knowledge on cannabis abuse with selected socio-demographic variable of undergraduate students $(\mathrm{N}=\mathbf{8 0})$

\begin{tabular}{|c|c|c|c|c|c|c|c|}
\hline \multirow[t]{2}{*}{ S.No. } & \multirow{2}{*}{ Variables } & \multirow{2}{*}{ Subcategories } & \multicolumn{2}{|c|}{ Level of knowledge } & \multirow{2}{*}{$x^{2}$} & \multirow[b]{2}{*}{ df } & \multirow{2}{*}{ p Value } \\
\hline & & & Average & Poor & & & \\
\hline \multirow{3}{*}{1.} & \multirow[t]{3}{*}{ Age } & $17-18 \mathrm{yrs}$ & 17 & 40 & \multirow{3}{*}{2.176} & \multirow{3}{*}{2} & \multirow{3}{*}{0.337} \\
\hline & & $19-20 \mathrm{yrs}$ & 9 & 12 & & & \\
\hline & & $21-22$ yrs & 0 & 2 & & & \\
\hline \multirow[t]{2}{*}{2.} & \multirow[t]{2}{*}{ Gender } & Male & 10 & 22 & \multirow{2}{*}{0.038} & \multirow[b]{2}{*}{1} & \multirow[b]{2}{*}{0.845} \\
\hline & & Female & 16 & 32 & & & \\
\hline \multirow[t]{3}{*}{3.} & \multirow[t]{3}{*}{ Residential Status } & Rural & 19 & 48 & \multirow{3}{*}{4.276} & \multirow{3}{*}{2} & \multirow{3}{*}{0.118} \\
\hline & & Urban & 6 & 6 & & & \\
\hline & & Semi Rural & 1 & 0 & & & \\
\hline \multirow[t]{5}{*}{4.} & \multirow{5}{*}{ Father's Education } & No formal education & 6 & 14 & \multirow{5}{*}{5.090} & \multirow{5}{*}{5} & \multirow{5}{*}{0.405} \\
\hline & & Primary & 3 & 10 & & & \\
\hline & & Secondary & 6 & 18 & & & \\
\hline & & Senior Secondary & 7 & 8 & & & \\
\hline & & Graduation & 4 & 4 & & & \\
\hline 5. & Mother's Education & No formal education & 2 & 17 & & 5 & \\
\hline & & Primary & 7 & 9 & & & \\
\hline & & Secondary & 14 & 20 & 8.819 & & 0.116 \\
\hline & & Senior Secondary & 1 & 6 & & & \\
\hline & & Graduation & 2 & 2 & & & \\
\hline 6. & Father's Occupation & Unemployment & 3 & 12 & & & \\
\hline & & Private Employee & 12 & 22 & & & \\
\hline & & Self Employment & 8 & 8 & & & \\
\hline & & Government Employee & 2 & 4 & 5.365 & 5 & 0.373 \\
\hline & & Retired & 0 & 1 & & & \\
\hline & & Farmers & 1 & 7 & & & \\
\hline 7. & Mother's Occupation & Private Employment & 2 & 4 & & & \\
\hline & & Government Employee & 1 & 4 & & & 0.208 \\
\hline & & Self Employed & 2 & 0 & 4.553 & 3 & \\
\hline & & Home Maker & 21 & 46 & & & \\
\hline 8. & Family Monthly Income (Rs.) & Below 5000 & 7 & 23 & & & \\
\hline & & $5001-10000$ & 16 & 20 & 年 & & \\
\hline & & $10001-20000$ & 2 & 7 & 4.280 & 3 & 0.233 \\
\hline & & Above 20001 & 1 & 4 & & & \\
\hline 9. & Family History & Yes & 3 & 8 & C 150 & & Cac \\
\hline & & No & 23 & & 0.159 & 1 & 0.690 \\
\hline
\end{tabular}

Table 4.7 In this study the stated hypothesis $\mathrm{H} 2:$. The result of the study revealed that majority of socio demographic variables was not significantly associated with pre test score of level of knowledge on cannabis abuse. Therefore the above stated hypothesis was rejected.

\section{DISCUSSION}

The findings of the study have been discussed in accordance with the objective of the study and previously reviewed literature.

In pre test $54(67.5 \%)$ undergraduate students' had poor knowledge, 26(32.5\%) had average knowledge whereas in post test$144(55 \%)$ had average knowledge, 36(45\%) 
had good knowledge and in post test 2 $48(60 \%)$ had average knowledge, 32(40\%) had good knowledge. In a similar study the findings reveal that in Pre test knowledge scores $91 \%$ of the students had average knowledge and $2 \%$ had poor knowledge whereas only $7 \%$ had good knowledge and in the post-test knowledge scores result shows that $52.8 \%$ students had good knowledge on cannabis abuse and its consequences. The indices show a steady increase in knowledge from $7.5 \%$ during the pre-test to $52.8 \%$ during the post test with a mean difference of 4.23 between pretest and post-test at 0.05 level of significance $(p>0.001)$ hence awareness programme helps students to gain knowledge and helps in enlightening their future. ${ }^{34}$

\section{Limitations}

$>$ The study was confined to a small number of subjects, which limits the generalization.

$>$ The study subjects from private colleges were not included because permission from the authorities not granted

$>$ The follow up assessment could not be collected due to lack of time

\section{CONCLUSION}

The results from this study revealed that educational programme significantly improved the level of knowledge among undergraduate Students on cannabis abuse so other teaching strategies can be used to increase undergraduate Students's knowledge on cannabis abuse.

Acknowledgement: None

Conflict of Interest: None

Source of Funding: None

Ethical Approval: Approved

\section{REFERENCES}

1. Vyas J,Ghimire S. Textbook of post graduate psychiatry.3rd edition, Jaypee publishers, page no 103 -194.

2. Aston $\mathrm{CH}$ et al. Adverse effect of cannabis and cannabinoids. British journal of anaesthesia.2012;83:637-47. Available from: https://pdfs.semanticschol..org/92dd /06df3616143db5bae0699a7d5c0828caca16 .pdf

3. Alan J Budney \& Catherine Stanger. IACAPAP Textbook of Child and Adolescent Mental Health, 2012Available from:

https://iacapap.org/content/uploads/TABLEOF-CONTENTS-2015.pdf

4. Madras BK. Update of Cannabis and its medical use, 37th ECDD (2015). Available from:https://www.who.int/medicines/access/ controlled-substances/62cannabisupdate.pdf

5. Balodis I and MacKillop J. Cannabis Use Disorder Recent Advances in Cannabinoid Research. Intech Open.2018. Available from:

https://www.intechopen.com/books/recentadvances-in-cannabinoid-research/ cannabis-use-disorder

6. Hall W, Solowij N. Adverse effects of cannabis. National Drug and Alcohol. Available from: http://www.drugpoint.org.au/drugs_and_the ir_effects/cannabis

/The_health_\%20and_psychological_effects _of_cannabis_use.pdf

7. Adverse effect of cannabis. Research Australia Lancet 1998; 352: 1611-16. Available from: https://www.thelancet.com/journals/lancet/a rticle/PIIS0140-6736(98)05021-1/fulltext

8. Hemant G. Role of cannabis in cardiovascular disorders. J Thorac Dis. 2017 ; 9(7): 2079-2092. Available from: https://www.ncbi.nlm.nih.gov/pmc/articles/ PMC5542986/

9. The narcotic drugs and psychotropic substances, act, 1985. Available from: https://indiacode.nic.in/bitstream/12345678 9/6380/1/mtp.pdf

10. Sharma P, ThakurA .Pattern of Substance Abuse in Patients Attending Psychiatry OPD of IGMC, Shimla. IOSR Journal of Dental and Medical Sciences (IOSRJDMS). 2014; 13 (8),67-70. Available from: www.iosrjournals.org 
Manisha et.al. Effectiveness of video assisted teaching programme on cannabis abuse on level of knowledge among undergraduate students.

11. Arevian MB, Khasholian TK. Impact of a Peer-led Educational Program on Knowledge and Attitudes about Prevention of Substance Abuse among Lebanese/Armenian Adolescents: A Pilot Study. J Community Med Health Educ. 2014;4:326. Available from: https://www.omicsonline.org/peerreviewed/impact-of-a-peerled-educationalprogram-on-knowledge-and-attitudes-aboutprevention-of-substance-abuse-amonglebanesearmenian-ado-37291.html

12. D Ramesh.Treatment of Cannabis Use Disorders .Burden of Disease: The Epidemiological Aspects of Addiction. 2014;367-380. Available from: https://www.researchgate.net/publication/27 2680757_Treatment_of_Cannabis_Use_Dis orders

13. Drugs and age- Drugs and associated issues among young people and older people PLOS ONE 11(10) . Available from: DOI: https://doi.org/10.1371/journal.pone.016522 1

14. UNODC ,drug and age, drug and associated problems among young and older people United Nations, June2018. Available from: https://www.unodc.org/wdr2018/prelaunch/ WDR18_Booklet_4_YOUTH.pdf

15. Ministry Of Social Justice And Empowerment Government Of India. Magnitude of substance abuse in India. 2019. Available from: http://socialjustice.nic.in/writereaddata/Uplo adFile/Magnitude_Substance_Use_India_R EPORT.pdf

16. Rebecca D, Natania A. Crane, and Barbara J. Mason. An Evidence Based Review of Acute and Long-Term Effects of Cannabis Use on Executive Cognitive Functions PMC NIH..2012; 5(1). 1-8.Available from: https://www.ncbi.nlm.nih.gov/pmc/articles/ PMC3037578/

17. Sharma P, ThakurA .Pattern of Substance Abuse in Patients Attending Psychiatry OPD of IGMC, Shimla ,IOSR Journal of Dental and Medical Sciences.2014; 13(8), 67-70 Available from: www.iosrjournals.org

18. Amelia M, Kimberly M. Caldeira. Acute cannabis consumption and motor vehicle collision risk: systematic review of observational studies and meta-analysis HHS Public Access Author manuscript Psychol Addict Behav . 2015; 29(3), 564-
575. Available from:https.//Amelia+M,+Kimberly+M.+Cal deira.+Acute+cannabis+consumption+and+ motor+vehicle+collision+risk:+systematic+r eview+of+observational+studies+and+meta

analysis + HHS + Public + Access + Author + ma nuscript+Psychol+Addict+Behav+.+2015;

19. Stephen Sidney. Cardiovascular Consequences of Marijuana Use, the journal off clinical pharmacology. 2014; 42(S1).Available from https://doi.org/10.1002/j.15524604.2002.tb06005.

20. Raymond J, Niesinkand M. Cannabidiol protect against adverse psychological effects of THC Psychiatry. 2013;4(13). Available from:https://doi.org/10.3389/fpsyt.2013.001 30

21. Tennes K, Avitable N, Carol M. Marijuana: Prenatal and Postnatal Exposure in the Human. NIDA research monograph. 1985;48-60.Available from: https://pdfs.semanticscholar.org/aeb0/fb3fd2 9aebdfbac779287081e80e5fed1 ae1.pdf?

22. Tullu $M$ et al Prevalence of Cannabis Use Disorder and Associated Factors among Cannabis Young Adult Users at Shashemene Town, Oromia Region, Ethiopia, 2016, Hindawi Psychiatry Journal.2018; 8.Available from: https://doi.org/10.1155/2018/6731341

23. Wayne, Degenhardt, Louisa. Prevalence and correlates of cannabis use in developed and developing countries .Current Opinion in Psychiatry: July 2007;20(4) ,393-397 Available from: https://www.ncbi.nlm.nih.gov/pubmed/1755 1355

24. Frederick S. Stinson, W. June Ruan .Cannabis use disorders in the USA: prevalence, correlates and co-morbidity. 2016; 36(10), 1447-1460, Available from: https://www.ncbi.nlm.nih.gov/pubmed/1685 4249

25. Navin Ket al.Cannabis use patterns at the dawn of US cannabis reform. Journal of Cannabis Research, 2019,(5):234270.Available from: https://www.ncbi.nlm.nih.gov/pmc/articles/ PMC6358421/

26. Deborah S, Hasin, Tulshi D. Saha. Prevalence of Marijuana Use Disorders in the United States Between 2001-2002 and 2012-2013. JAMA Psychiatry. $r$ 2015; 
Manisha et.al. Effectiveness of video assisted teaching programme on cannabis abuse on level of knowledge among undergraduate students.

72(12): 1235-1242. Available from: https://www.ncbi.nlm.nih.gov/pmc/articles/ PMC5037576/

27. Yasir HR, Fazl E R.. Profile of Cannabis users Seeking Treatment at Government DeAddiction Center in a Tertiary Hospital. Kashmir International Journal of Contemporary Medical Research. 2017;4(10):73-83. Available from:https://www.ijcmr.com/uploads/7/7/4/ 6/774664738/ijcmr_1698.pdf

28. Singh S, Balhara YP. A review of Indian research on co-occurring cannabis use disorders\& psychiatric disorders. Indian J Med Res. 2017;146:186-95Available from:http://www.ijmr.org.in/article.asp?issn $=09715916$; year $=2017 ;$ volume $=146$; issue $=2$ ; spage $=186$; epage $=195$; aulast $=$ Singh

29. Renuka J. Drug use in a rural community in Bihar: Some psychosocial correlates. Indian Journal of Psychiatry. 1998 38(1):43-6 • Available from: https://www.ncbi.nlm.nih.gov/pmc/articles/ PMC2970780/

30. Antti M, Solja N. The Adolescent cannabis use, baseline prodromal symptoms and the risk of psychosis. British Journal of Psychiatry. 2018; 212(4): 227-233. Available from: https://doi.org/10.1192/bjp.2017.52

31. Powell-BK, Haye W, Mills $S$.Impact of cannabis on the neurocognitive performance of Jamaican adolescents. Ment Health Addict Res. 2016; 1(3), 71-73.Available from:10.15761/MHAR.1000118

32. Aldington S, Williams $M$, Nowitz $M$. Effects of cannabis on pulmonary structure, unction and symptoms. PubMed. 2007;62(12):1058-63. Available from: https://www.ncbi.nlm.nih.gov/pubmed/1766 6437

33. Bechtold J, Simpson T, White HR, Pardini D.Chronic adolescent marijuana use as a risk factor for physical and mental health problems in young adult men.Psychol Addict Behav. 2015;29(3):55263.Available from: 10.1037/adb0000103.

34. Rosalie M. Berberian, Cynthia Gross, Jennifer Lovejoy, The Effectiveness of Drug Education Programs: A Critical Review, PubMed, 1976, 4(4), 377-398 Available from:

https://www.ncbi.nlm.nih.gov/pubmed/9183 110

How to cite this article: Manisha, Jegannathen J. Effectiveness of video assisted teaching programme on cannabis abuse on level of knowledge among undergraduate students. International Journal of Science \& Healthcare Research. 2021; 6(2): 156-163. DOI: https:// doi.org/10.52403/ijshr.20210428 